Journal of Universal Language 14-2

September 2013, 53-78

\title{
The Morphosyntactic Coding of Focus Structure in Igbo
}

\author{
Maduabuchi Sennen Agbo \\ University of Benin
}

\begin{abstract}
Cross-linguistic studies have ascertained that the information units within clause structure are systematically coded. These information units shape the information structure of the clause and focus structure is the term for it in the literature. Previous studies on Igbo focus structure centre exclusively on the syntactic derivation of the clause to determine the focus structure. Therefore, this study investigates how pragmatic considerations and morphological markings in the clause structure determine the various types of Igbo focus structure. The study adopts the Role and Reference Grammar (RRG) framework, which seeks out the relationship between referring expressions in a clause and the focus structure. RRG also has the advantage of formally projecting focus structure into the representation of clause structure. Four categorical types of focus structure occur in Igbo.

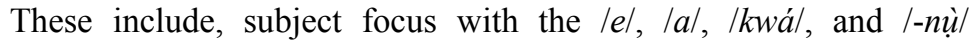

\footnotetext{
Maduabuchi Sennen Agbo

Department of Linguistics and African Languages, Faculty of Arts, University of Benin, PMB 1154, Benin City, Edo State, Nigeria

Phone: +234-8056021759; Email: maduagbo@gmail.com
}

Received July 6, 2013; Revised August 27, 2013; Accepted September 3, 2013. 
54 The Morphosyntactic Coding of Focus Structure in Igbo

markers; object focus with /mál and /kál as markers; verb focus with /weé/, /nàl, and /gál as markers and sentence focus with gwá $\dot{m}$ and $/ g h i ́ \mid$ as markers. The study reveals that morphological markings code focus structure in Igbo. In other words, it describes the information units within clause structure from the perspective of the interaction between morphology, pragmatics, and syntax, and not exclusively from a syntactic perspective.

Keywords: Igbo, focus structure, morphosyntax, Role and Reference Grammar

\section{Introduction}

Linguistic expressions systematically code information units within the clause structure, and even beyond it. The grammatical term focus structure is the nomenclature for the encoding of information units in linguistic expressions. Cross-linguistic studies of focus structure have established this grammatical operation as a universal property of language. Schachter (1973), Hyman \& Watters (1984), Nwachukwu (1995), Cook (2002), Wolf \& Löhr (2006), and Aboh et al. (2007) among others present detailed analyses of focus constructions in various languages. These analyses have a common understanding of focus as 'that information in an utterance which the speaker believes, assumes, or knows that the hearer does not share with him/her' (Hyman \& Watters 1984: 237). Again, 'focus refers to that part of the clause that provides the most relevant or most salient information in a given discourse situation' (Aboh et al. 2007: 1).

This paper will be specifically concerned with how focus is morphologically marked within the syntactic structure of the Igbo ${ }^{1}$

1 Igbo is one of the three major indigenous languages of Nigeria and it is spoken by about thirty million people. Williamson \& Blench (2000) classify Igbo as West Benue-Congo under the Niger-Congo language family. It is a tone language 
clause, and also, the relationship between these markings and the context of usage. As a verb-centred language some of these morphological markings will be affixes attached to the verb. However, other morphological markings occur elsewhere in the clause. The paper makes the assumption that the Igbo clause is structured in terms of information units within it. In other words, the clause contains two components. The first component consists of the 'old information' while the second component consists of the 'new information.' The old information includes the part of the clause that 'the speaker shares with the listener.' The new information is the part of the clause that brings about 'communication dynamism.' That is, the part that contains information that is not shared by the speaker with the listener. In the literature, the two components of 'old information' versus 'new information' are referred to as topic versus comment and theme versus rheme. This opposition is known as the information structure of the clause. In all these, morphological markings contribute to the determination of information structure.

This paper follows the Role and Reference Grammar (RRG) theory with the assumption that

'focus structure affects the type of referring expression that is selected to fill a variable position in Logical Structure (LS) because the kind of referring expression that is chosen reflects the status of the referent in the discourse content' (van Valin 2005: 73).

RRG also has the advantage of the straightforward and elegant representation of focus structure.

The analyses focus greatly on the interaction between Igbo verbal morphology and focus structure. In the literature, it is known that all affixes in the clause are attached to the verb. These 
affixes implicitly are referred to as inflexional affixes. However, in this study, we assume these affixes to be expressive affixes in the light of Scalise (1984), Fortin (2011), Körtvelyessy \& Stekauer (2011), Efthymiou (2013), and di Garbo (2013). Expressive affixes are representative of some referents within the clause structure. Their function is different from inflexion suffixes which modulate the event structure of the verb. Agbo $(2010,2013)$ argues that the event structure of the Igbo verb is inherently encoded in its Logical Structure and cannot be determined by affixes. The function of expressive affixes is understood within a communicative context. Expressive affixes give the speaker's point of view in relation to any of the referents in the communicative situation. These affixes also function to determine the modulation of the event structure from the perspective of the speaker. Expressive affixes do not only attach to verbs. Indeed, these affixes do attach to nouns in the clause. In other words, one could argue that all Igbo affixes within the clause are expressive affixes (Agbo (In Preparation)).

\subsection{Data Sources and Methodology}

The clauses derive from a variety of published and unpublished sources. These include two books of Igbo prose fiction: Ómàlinzè, a book of Igbo folktales and Ńzá nà Òb̀̀. The other source includes Áká Wètá, a book of poems.

The clause forms essential for the study were derived from these texts. With regards to the objective of this study, these clause forms were presented to twenty-five native speakers of the Nsụkka, Nnewi, and Owerri dialects for validation. Additional data were elicited from these native speakers in line with the stated objectives. The writer who is a competent native speaker of the Nsụkka variety also provided more data by introspection. The data were then methodically described and the analysis of the focus structure followed afterwards. 


\subsection{Previous Study of Focus Structure in Igbo}

Nwachukwu (1995) seems to be the only significant account of focus structure in Igbo. His work is a structural analysis of focus constructions where the syntax of the language determines information units, therefore, the focus structure of the clause. $\mathrm{He}$ applies move- $\alpha$ rules of Transformational Generative Grammar in his analysis. Nwachukwu's (ibid.) reliance on move- $\alpha$ presents an analysis denying any role to morphology and the context of usage in focus constructions. Again, the analysis seems to assign the same structure to relative clause formation and focus. However, linguistic literature (Schachter 1973, Hyman \& Watters 1984, de Vries 2006, Letsholo 2009 among others) is replete with the distinction between relative clause formation and focus construction. Nwachukwu's analysis has not distinguished Igbo relative clause construction from focus constructions. This can be attributed to his purely syntactic approach to the problem which has given rise to this vague differentiation. The objectives of this paper do not include this differentiation.

The paper therefore seeks to expand the description of the scope of focus to include the role of morphology and the context of use of the clause in addition to the role of the syntactic structure.

\section{The Scope of Focus in Igbo}

The grammatical structure of Igbo morphologically indicates focus structure and the types of focus. These include the marking out of information units within the clause into the broad categories of narrow versus broad focus types. The narrow focus types include the marking of focus on only one component among the information units and/or clause structure, viz. subject, object, verb, and other lexical categories. Broad focus on the other hand 
includes the marking out of more than one element as the focus and this may range from a phrase of two lexical items to the whole clause.

The rest of the paper is organised thus. Section 2.1 to 2.4 .2 discusses the types of Igbo focus structure, section 3 presents a formal representation of focus structure and examines it in detail while section 4 is the conclusion of the study.

\subsection{Subject Focus}

Subject focus occurs when the 'new information' that the listener does not share with the speaker is expressed by the subject of the clause. In Igbo, subject focus markers include the morphemes $e, a, k w a ́$, -nù, the progressive marker nà, and the tense marker $g a ́ .^{2}$

\subsection{1. $E$ and $A$ Subject Focus Markers}

Examples (1a-c) illustrate subject focus constructions marked by the $e$ and $a$ subject focus markers.

2 The transcription follows standard Igbo orthography: à (low tone); á (high tone); and $\bar{a}$ downstep. All tones are marked to avoid ambiguity due to lexical variance among the dialects. Igbo has the phonological features of vowel harmony where the eight vowels in the language are neatly divided into two sets. One set comprises vowels produced with the Advanced Tongue Root (+ATR) while the other set comprises vowels with -ATR. In standard Igbo, -ATR vowels are represented with the sub-dot, e.g., [o], while +ATR vowels do not have the sub-dot. The abbreviations used are: FOC-focus, IND-indicative, BENbenefactive, ABS-absolutive, PL-plural, SG-singular, 3SG (subj)-third person singular for subjects, 3SG (obj)—third person singular for objects, 3PLthird person plural, DEM-demonstrative, $\mathrm{PROG}$ - progressive, NEG-negative, AGR-agreement marker, AUX-auxiliary, IMP-imperative, CONJconjunction 
(1) a. É kùzì-rì hà ákwựkwộ.

FOC teach-IND 3PL book

'They have been taught academics.'/‘They have been educated.'

b. Á tụ̀-ụ̀-rụ̀ Àda íme.

FOC throw-BEN-IND Ada pregnancy

'Ada has been made pregnant.'

c. Á zà-rà úlọ̀.

FOC sweep-IND house

'The house has been swept.'

In (1a) the morpheme $\dot{e}$ which is the subject focus marker makes reference to an unnamed subject in the discourse context. This unnamed subject is the agent in the clause. The morpheme $a ́$ in examples $(1 \mathrm{~b} \& \mathrm{c})$ fulfils similar functions as explained for example (1a). The morphemes $-r i$, $-r u$, and $-r a$ are identified as $-\mathrm{rV}$ suffixes in Igbo syntax and they are indicative morphemes which express the natural facts about the verbs. The focus marker functions of the morphemes $e$ and $\dot{a}$ are highlighted in examples $(2 \mathrm{a}-\mathrm{c})$ where they operate to emphasise the action of the agent.

(2) a. Àdá è-kúzí-gó há ákwụ́kwọ̄. Ada FOC-teach-ABS 3PL book

'Ada has comprehensively taught them academics.'/

'Ada has absolutely educated them.'

$\begin{array}{llll}\text { b. Òbí } & \text { à-tú-gō } & \text { Àdá } & \text { ímē. } \\ \text { Obi } & \text { FOC-throw-ABS } & \text { Ada } & \text { pregnant }\end{array}$

'Obi has indeed got Ada pregnant.'

c. Ézè á-zà-gō ụ́lọ̀.

Eze FOC-sweep-ABS house

'Eze has swept the house.'/'Eze has indeed completed the sweeping of the house.' 
In (2a-c) the morphemes $e$ - and $a$ - (in this case verbal prefixes) bring to focus the particular agent in the clause by cross-referencing them in the communicative event. In other words, these morphemes, in an explicit way, specify the subject in the clause. Note however that for this function to be operational the verbs must not take an indicative suffix (cf. 1a-c). The suffix of the verb must be able to communicate to the listener not the natural facts about the verb but the gradation of the event structure. The morpheme -gó in (2a-c) are absolutive markers found in the data. Other suffixes that can be taken by these verbs are relational suffixes like -la and -le which convey the notion of the relation between the time of utterance and the time the event was carried out.

The $e$ - and $a$ - subject markers can only cross-reference animate agents and only co-occur with achievement verbs (Agbo 2010). This seems to be so because the actions of the achievement verbs can be predicated only on animate agents. Again, $e$ - prefixes to verb roots with + ATR vowels while $a$ - prefixes to verb roots with -ATR vowels.

\subsubsection{Kwá Subject Focus Marker}

The kwá subject marker immediately follows the subject in the clause and functions to accentuate the fact that the subject is indeed the agent of the event the verb encodes. Examples (3a-c) below illustrate how kwá functions as subject focus marker.

(3) a. Òbí kwá bì̀-rà.

Obi FOC come-IND

'Obi (unexpectedly) also came.'

b. Gí kwá mè-rè íhé á. 2SG FOC do-IND thing DEM 'You (of all persons) also did this thing.' 

c. Òbí nà Àdá kwá bì̀-rà. Obi CONJ Ada FOC come-IND 'Obi and Ada (unexpectedly) also came.'

Kwá in (3a) gives emphasis to Òbí, the subject of the clause and introduces it as the focus element in the discourse. The same explanation goes for $(3 \mathrm{~b} \& \mathrm{c})$ where $k w a$ marks out the subjects gí and Òbi nà Àdá. Kwá is also a verb focus marker as will be shown in section 2.3.5.

\subsection{3. -Nụ Subject Focus Marker}

-Nù is regarded as a clitic in Igbo syntax (Emenanjo 1978, Mbah et al. 2012). However, in this study it is observed that -nì suffixes to verbs and functions to be the subject focus marker in the clause. This is illustrated in (4a-c) below.
(4) a. Gáá-nụ̀
Àbá.
go-FOC
Aba
'Go to Aba.'
b. Ríé-nụ̀ ńrī. eat-FOC food
'Eat food.'
c. Nựộn-nụ̀ mmányā.
drink-FOC wine
'Drink wine.'

Note that the focus marker -nù in (4a-c) suffixes to the verbs. Their function is to identify the unnamed subject in the clause. This subject is the second person plural pronoun, únù. This claim bears out with the re-phrasing of $(4 a-c)$ in $(5 a-c)$. 
62 The Morphosyntactic Coding of Focus Structure in Igbo

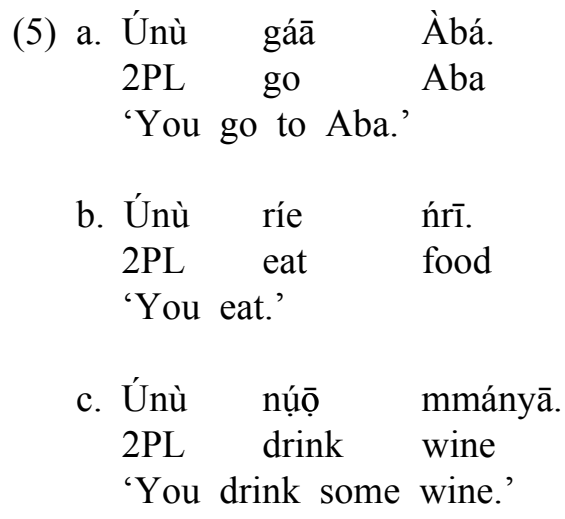

In $(5 \mathrm{a}-\mathrm{c})$ the second person plural pronoun únù occurs in the subject position and the non-appearance of the -nù as a suffix indicates that the whole clause is the focus of the utterance. Nonetheless, sentences like (6a-c) where the second person plural pronoun únù and the focus marker -nù co-occur exist. In such sentences, the -nù focus marker serves to further emphasise the subject of the clause únù by bringing it to spotlight.
(6) a. Únù gáa-nụ̀ Àbá. 2PL go Aba
'You go to Aba.'
b. Únù ríē-nụ̀ ńrī. 2PL eat food
'You eat.'
c. Únù ñụ̂ộ-nụ̀ mmányā.
2PL drink wine
'You drink some wine.'




\subsection{Object Focus}

Object focus is explicit in verbs where the activity of the agent completely affects that of the patient of the clause. In other words, object focus occurs with transitive verbs in the light of Agbo \& Yuka (2011) and Agbo (2013), where a transitive verb in Igbo is one in which the agent/subject carries out an action that totally affects the patient/object. Object focus markers include má and ká.

\subsubsection{Má Object Focus Marker}

The má object focus marker immediately precedes the object in the clause and expectedly serves to highlight it as the object of the clause. The examples in $(7 \mathrm{a}-\mathrm{c})$ demonstrate this statement.
a. Àdá zụ̀-rụ̀ éwū nà jí. Ada buy-IND goat and yam
'Ada bought a goat and some yams.'
a'. Àdá zụ̀-rụ̀ má éwū má jí. Ada buy-IND FOC goat FOC yam
'Ada bought a goat and some yams.'
$\begin{array}{lllll}\text { b. Òbí } & \text { wè-rè } & \text { má } & \text { íhùnányā lụ̂ộ } & \text { Àdá. } \\ \text { Obi } & \text { take-IND } & \text { FOC } & \text { love marry } & \text { Ada }\end{array}$ 'Obi married Ada for love.'

c. Há hù-rù má nné há má nná há. 3PL see-IND FOC mother 3PL FOC father 3PL 'They saw both their father and mother.'

In (7a) above, the focus structure is the whole clause but with the introduction of the object focus marker $m a$ in (7a') the focus is narrowed down to the objects ewú and jí. In ( $7 \mathrm{~b} \& \mathrm{c})$ the focus marker precedes the objects ihùnánya and nné há and nná há 
respectively. Thereby bringing these objects to focus. Note that the object marker má cannot precede the verb. Otherwise, ungrammatical clauses like (8a-c) arise.

(8) a. *Ada ma zụ̀-rụ̀ éwū jí.

Ada FOC buy-IND goat yam

'Ada bought a goat and some yams.'

b. *Òbí má wè-rè ìhùnánya lụ̣ộ Àdá.

Obi FOC take-IND love marry Ada

'Obi married Ada for love.'

c. *Ha má hù-rù nné há nà nná há.

3PL FOC see-IND mother 3PL CONJ father 3PL

'They saw both their father and mother.'

\subsubsection{Ká Object Marker}

The $k a$ morpheme immediately follows the object in the object focus construction. Nwachukwu (1995) considers these constructions to result from movement rules, where the object is moved to a clause initial position in the surface structure of the transformational operation. The focus of this paper is the morphosyntactic coding of focus within such constructions. The sentences in $(9 \mathrm{a}-\mathrm{c})$ below show these coding operations.

(9) a. Ńri ká Àdá rì-rì. food FOC Ada eat-IND

'It is food that Ada ate.'

b. Lìngwístíkìs ká ọ́ gụ̀-rừ. linguistics FOC 3SG (subj) read-IND

'It is Linguistics that s/he studied.' 


$\begin{array}{lll}\text { c. Èkpéré ká } & \text { Àdá } & \text { kpè-rè. } \\ \text { prayer FOC Ada } & \text { pray-IND } \\ \text { 'It is prayer that Ada said.' } & \end{array}$

The $k \dot{a}$ morpheme cannot occur elsewhere in the clause otherwise the construction will be ungrammatical. In other words, its canonical position for object marking is as shown in (9a-c) above.

\subsection{Verb Focus}

Verb focus arises when the focus marker attaches to the verb or in some instances it precedes the verb in the focus construction. Verb focus markers include the morphemes nà, gá, weé, and the various expressive suffixes (that are dialectal) that attach to the verbs.

\subsubsection{Nà Focus Marker}

In the literature, $n \grave{a}$ is a progressive marker and Emenanjo $(1978,1985)$ ascribes the grammatical category of auxiliary verb to $n a ̀$. In our data nà also functions as an expressive morpheme to focus a particular attribute of the agent in the clause. Consider the Nnewi dialect examples in (10) and (11).
(10) a. Ọ́
nà-á-yà
ọ́yà.
3SG (subj)
PROG-AGR-sick
sickness
' $\mathrm{S} / \mathrm{he}$ is sick.'
b. Ọ́
nà-à-jó
ńjō.
3SG (subj)
PROG-AGR-V
badness
' $\mathrm{S} /$ he is stingy.' 
c. OQ́

nà-è-ghú

PROG-AGR-V

3SG (subj)

' $\mathrm{S} / \mathrm{he}$ is jealous.' ányaọ́kụ̣.

jealous

(11) a. Ọ́ nà-á-yà.

3SG (subj)

$\mathrm{FOC}_{1}-\mathrm{FOC}_{2}$-sick

' $\mathrm{S} /$ he is always sick.'

b. Ớ

nà-à-jō.

3SG (subj)

$\mathrm{FOC}_{1}-\mathrm{FOC}_{2}-\mathrm{V}$

' $\mathrm{S} / \mathrm{he}$ is a bad person.'

c. OQ́

nà-è-ghú.

3SG (subj)

$\mathrm{FOC}_{1}-\mathrm{FOC}_{2}-\mathrm{V}$

' $\mathrm{S} / \mathrm{he}$ is jealous as a habit.'

In (10a-c) nà functions as a progressive marker. This is the generic function of nà. However, in (11a-c) the function changes to that of a verbal focus marker. Observe that in (11a-c) the complements of the verbs (viz. óyà, njó, and ányaokứ respectively) are missing. This also results in a change in the reading of the clause. The function of $n a ̀$ in $(11 \mathrm{a}-\mathrm{c})$ is to highlight the fact that the agent of the clause peculiarly exhibits the activity the verb encodes. So in (11a-c) there are two focus markers, $\mathrm{FOC}_{1}$ and $\mathrm{FOC}_{2} . \mathrm{FOC}_{1}$ is a verbal focus marker while $\mathrm{FOC}_{2}$ is a subject focus marker as exemplified in section 2.1.1.

\subsubsection{Gá Focus Marker}

The gá morpheme is also considered an auxiliary verb and a future tense marker in the literature (Emenanjo 1978, 1985; Uwalaka 1997). It is realised as [dza], $j a ́$ in the Nsukka dialect. As with the case of $n a ̀$ the available data indicates that gá also functions to express the synchronicity of an event with another concurrent one. 
Consider the Nsukka dialect examples in (12) and (13).

(12) a. Òbí já à-bía.

Obi FUT AGR-come

'Obi will come.'

b. Òbí já à-lá.

Obi FUT AGR-return

'Obi will return.'

c. Òbí já è-rú ứlọ̀.

Obi FUT AGR-reach house

'Obi will reach home.'

(13) a. Òbí bìa-jà.

Obi come-FOC

'Obi is coming.'

b. Òbí là-jà.

Obi return-FOC

'Obi is returning.'

c. Òbí rù-já.

Obi reach-FOC

'Obi is reaching.'

In (12a-c) já encodes a future tense reading to the clause. In (13a-c) the reading of the clause changes to one that is being synchronised with another event in the communicative context. Therefore, in (13a) the coming of Obi is parallel to another event not mentioned in the clause and $j a ́$ is the focus marker for that event. The same analysis applies to $(13 b \& c)$. 


\subsubsection{Weé as Verb Focus Marker}

Emenanjo (1985: 146) defines the morpheme weé as a 'pre-verb that functions as a linker of the clause' in both the Igbuụzo and Nnewi dialects. This pre-verb always precedes the verb of the clause it linking with the antecedent clause. Weé, according to Emenanjo (1985: 70), "is clearly derived from weé 'take." The Nnewi data in this study confirms Emananjo's (1981) claim. Nonetheless, our claim in this study is that wee is a verb focus marker often used in conversations. The clauses in (14a-c) illustrate this function of weé.
(14) a. Ò weé sí-ē ńrī. 3SG FOC cook-IMP food 'S/he then cooked.'
b. Òbí weé dáá n'àlà. Obi FOC fall on ground 'Obi then fell on the ground.'
c. Há weé gbá égwū. 3PL FOC $\mathrm{V}$ dance
'They then danced.'

As (14a-c) illustrates, weé always precedes the verb in the clause and its occurrence in a different position results in ungrammatical clauses. The role of wee is to underscore the verb representing the action taken by the agent in the clause.

\subsubsection{Causative Altemation as Verb Focus Marker}

Uwalaka (1988) identifies a class of Igbo verbs known in the literature as 'subject-object switching verbs' (or Ergative Complement Verbs by Emenanjo 2005). This is because this class 
of verbs has the unique feature of being able to alternate the positions of the nominals in the clause and still retain the essential meaning of it. However, Agbo (2013) based on arguments of the inherent temporal features of these verbs, identifies them as having the features that enable them to undergo causative alternation. In other words, when the positions of the nominals are interchanged, a causative reading is adduced to the clause.
a. Òkónkwō pụ̀-rụ̀ árá.
Okonkwo go-out mad
'Okonkwo is mad.'
a'. Árā pụ̀-rụ̀ Ókónkwō.
madness FOC Okonkwo
'Okonkwo is mad.'

\begin{tabular}{|c|c|c|}
\hline $\begin{array}{l}\text { b. O } \\
\text { 3SG (subj) } \\
\text { ' } \mathrm{S} / \mathrm{he} \text { is lame.' }\end{array}$ & $\begin{array}{l}\text { kụ̀-rụ̀ } \\
\text { hit-IND }\end{array}$ & $\begin{array}{l}\text { ǹgwọ́rọ̀. } \\
\text { lameness }\end{array}$ \\
\hline $\begin{array}{l}\text { b'. Ngwóró } \\
\text { lameness } \\
\text { 'S/he is lame.' }\end{array}$ & $\begin{array}{l}\text { kùrù } \\
\text { FOC }\end{array}$ & $\begin{array}{l}\text { yá. } \\
\text { 3SG (obj) }\end{array}$ \\
\hline $\begin{array}{l}\text { c. Òbí } \\
\text { Obi } \\
\text { 'Obi is daft.' }\end{array}$ & $\begin{array}{l}\text { dà-rà } \\
\text { fall-IND }\end{array}$ & $\begin{array}{l}\text { ìbèríbè. } \\
\text { daftness }\end{array}$ \\
\hline $\begin{array}{l}\text { c'. Ìbèríbe } \\
\text { daftness } \\
\text { 'Obi is daft.' }\end{array}$ & $\begin{array}{l}\text { dàrà } \\
\text { FOC }\end{array}$ & $\begin{array}{l}\text { Òbí. } \\
\text { Obí }\end{array}$ \\
\hline
\end{tabular}

The examples in (15a', b', $\left.c^{\prime}\right)$ show the alternation of the positions of the nominals in the clauses in $(15 \mathrm{a}, \mathrm{b}, \mathrm{c})$. One can see that the meaning of the clauses remain the same in spite of these alternations. The examples in (15a', b', c') are focus constructions where the verb takes on a causative reading and 
70 The Morphosyntactic Coding of Focus Structure in Igbo

functions to emphasise to the listener what is happening to the patient participant in the clause. In other words, $(15 \mathrm{a}, \mathrm{b}, \mathrm{c})$ are canonical clauses with no focus marking.

\subsubsection{Kwá Verb Focus Marker}

As mentioned in section 2.1.2 $\mathrm{kwá}$ in addition to functioning as a subject focus marker also functions as a verb focus marker. This function is illustrated in (16a-c) where $k w a ́$ is a suffix on the verb preceding the indicative-rV suffix.

(16) a. Òbí bì̀-kwà-rà.

Obi come-FOC-IND

'Obi in addition to others has come.'

b. Ada mè-kwà-rà ya.

Ada do-FOC-IND thing

'Ada in addition to others has done it.'

c. Òbí nà Àdá rì-kwà-rà jí.

Obi CONJ Ada eat-FOC-IND yam

'Obi and Ada in addition to other things ate some yam.'

The readings of the sentences (16) clearly show that $k w a$ is an additive in the sense that it brings to focus the activity described by the verb in an addition to other activities earlier done by the agents. For Nnewi, this additive focus marking property is realised not as a suffix on the verb but as an independent $k w a$ morpheme that is clause final. Examples (16a-c) re-presented as in (17a-c) below illustrates this Nnewi fact.

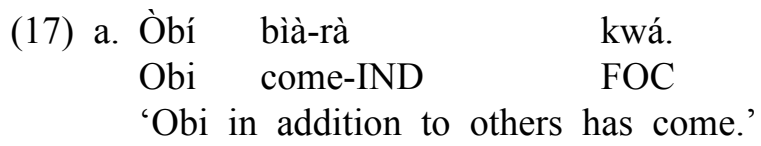


b. Àdá mè-rè yá kwá. Ada do-IND 3SG (obj) FOC

'Ada in addition to others has done it.'

c. Òbí nà Àdá rì-rì jí kwá.

Obi CONJ Ada eat-IND yam FOC

'Obi and Ada in addition to other things ate some yam.'

\subsection{Sentence Focus}

Sentence focus includes clauses where the information unit comprises all the constituents of the clause. Sentence focus in the data includes clauses that are introduced by gwá 'm 'tell me' and the negative suffix -ghí.

\subsubsection{Gwá $\dot{m}$ as Sentence Focus Marker}

Gwá $\dot{m}$ introduces riddles in the language. The art of telling riddles and finding out their meanings is a well known type of oral performance in Igbo literature. In the data, gwá $\dot{m}$ precedes the subject of the clause and it occurs nowhere outside that position. The data is exemplified with (18a-c).

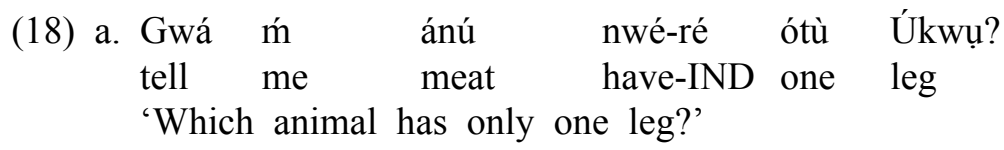

b. Gwá ḿ nwá má-rá mmá à-ná-ghí tell me child V-IND beauty FOC-PROG-NEG é-kù n'áká? AGR-carry in hand 'Which beautiful child cannot be carried in the arms?' 
72 The Morphosyntactic Coding of Focus Structure in Igbo

c. Gwá ḿ ó nwè-rè úrù è-nwé-ghí ókpúkpú? tell me 3SG have-IND value AGR-have-NEG bone 'What has value but no bones?

Gwá $\dot{m}$ in (18a-c) is indeed a sentence focus marker. It refers the listener to information outside the immediate communication event but within the cognitive experience of the listener. In other words, it prods the listener to relate the answer to the riddle to something within his/her world view. This answer is the new information that gwá $\dot{m}$ brings to focus and intends the listener to assume as 'new information.' Therefore, the answer to (18a) which is éró 'mushroom' is the 'new information.' In a similar vein are the answers to $(18 \mathrm{~b} \& \mathrm{c})$ which are ókú 'fire' and $j i$ 'yam' respectively. (18a-c) can then be re-presented as (19a-c) where gwá $\dot{m}$ is simply indicated as a focus marker and not its literal translation.

(19)

$\begin{array}{lllll}\text { a. Gwá ḿ } & \text { ánú } & \text { nwé-ré } & \text { ótù } & \text { Úkwụ? } \\ \text { FOC } & \text { meat } & \text { have-IND } & \text { one } & \text { leg }\end{array}$

'Which animal has only one leg?'

b. Gwá ḿ nwá má-rá mmá à-ná-ghí FOC child V-IND beauty AGR-PROG-NEG é-kù n'áká?

AGR-carry in hand

'Which beautiful child cannot be carried in the arms?'

c. Gwá ḿ ó nwè-rè úrù è-nwé-ghí ókpúkpú? FOC 3SG have-IND value AGR-have-NEG bone 'What has value but no bones?'

\subsubsection{The Negative Suffix as Sentence Focus Marker}

The morpheme $-g h i ̣$ is a negative suffix in the Owerri dialect. 
Other negative suffixes include -gho for Nsukka, -họ for Nnewi, and -ró for Onitsha. These dialectal suffixes all function as sentence and not constituent negators. In these functions they also communicate the whole event as the focus structure. (20a-c) which is data from Owerri illustrate this.
a. Há á-ná-ghị
à-bíá.
3PL FOC-PROG-FOC
AGR-come
'They are not coming.'
b. Àdá á-chó-ghí
égó.
Ada AGR-want-FOC
money
'Ada doesn't want money.'
c. Òbí é-chèzò-ghị nná yá.
Obi FOC-forget-FOC father 3SG (obj)
'Obi hasn't forgotten his father.'

Note that the $-g h i$ suffix can be replaced by other negative suffixes from other dialects and still retain the meaning of the sentences. The examples in (20a-c) without the -ghí suffix has the presupposition that the events denoted by the verbs take place. However, -ghi brings in the new information that the event denoted by the verb is negated. So -ghị as a focus marker expresses the negation of the event as the information the listener does not share with the speaker.

\section{The Formal Representation of Focus Structure}

The focus structure of clause in section 2 can be integrated into the clause structure representation within the RRG framework. This is because focus structure is related to clause structure. For 
74 The Morphosyntactic Coding of Focus Structure in Igbo

Igbo, the basic information units are formed by the verb, its arguments (in this case the subject and the object) and the morphemes. In RRG terms the verb constitutes the nucleus of the clause while the subject and object constitute the arguments. The morphemes comprise of the operator projections of the clause. These express the context of the communication event. Each focus projection has a potential focus domain and actual focus domain. For Igbo the whole clause forms the potential focus domain while the actual focus domain depends on the morphosyntactic dynamics of the clause.

The focus projection is represented in Figure 1 below. The diagram takes example (19a) above as the reference for all the clauses in the data. The focus marker gwá $\dot{m}$ is spelt out without a pause between it and the rest of the clause. This is known as the pre-core slot (PrCs). The smallest focus domain is each of the constituents of the clause made up of the nucleus and the two arguments as shown. The potential focus domain is represented by the triangular shape which encompasses all the minimal information units except the pre-core slot gwá $\dot{m}$. The potential focus domain is the represented by the arrowed lines. The operator projections are represented by the type of speech act. This speech act encodes the dynamism of the communicative event and the expressive affixes are represented by the focus projections. 
Figure 1. Focus Structure Representation of Igbo

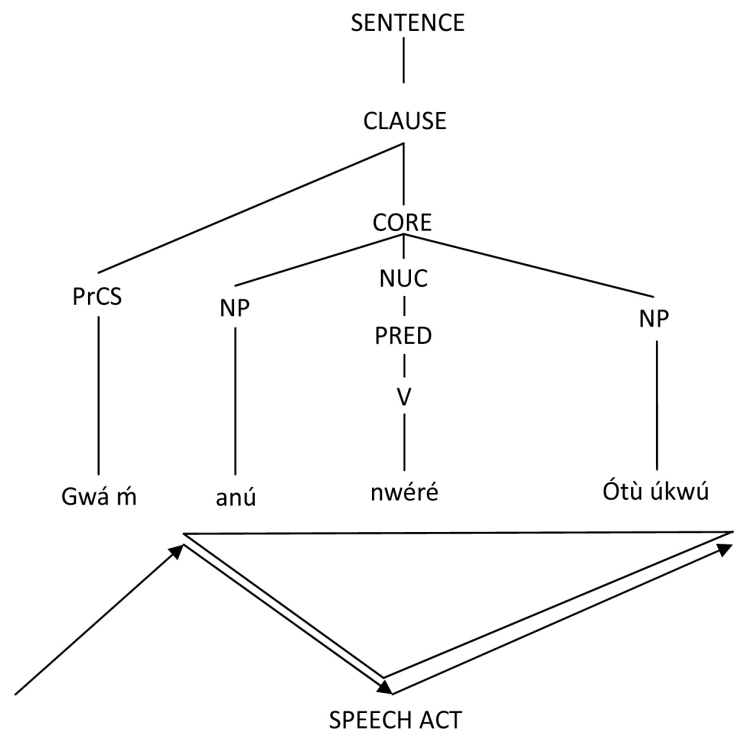

\section{Conclusions}

The discussion of focus structure in this work shows the close relationship between the expressive functions of morphemes and the context of usage of the morphemes in the language. It is this close relationship that codes the focus structure of the language. It is remarkable that the morphemes studied in this work are not exhaustive but they help to categories the focus types and scope of focus in the language. The formal representation of focus structure in section 3 is evidence that the morphosyntactic coding of Igbo focus structure gets an elegant representation in the RRG framework. In conclusion, Igbo demonstrates the characteristic feature of in-situ focus strategy. This is unlike English and some other African languages, for example, Hausa (Hartmann \& 
Zimmerman 2007), Gungbe (Aboh 2007), and Kikuyu (Schwarz 2007), which in addition to the in-situ focus strategy also exhibit ex-situ focus.

The hope is that the analysis presented here will prompt further inquiries into the focus structure of other Igbo dialects in order to have a more broad based perspective of the morphosyntactic coding of focus structure in Igbo.

\section{References}

Aboh, E. 2007. Focus versus Non-Focused Focus Wh-Phrases. In

E. Aboh et al. (eds.), Focus Strategies in African Languages:

The Interaction of Focus and Grammar in Niger-Congo and Afro-Asiatic 287-314. Berlin: Walter de Gruyter.

Aboh, E. et al. (eds.) 2007. Focus Strategies in African Languages: The Interaction of Focus and Grammar in

Niger-Congo and Afro-Asiatic. Berlin: Walter de Gruyter.

Agbo, M. 2010. Verb Classification and Aktionsart. California Linguistic Notes 35.1, 1-21. . 2013. A Role and Reference Grammar Analysis of the

Igbo Verb. Ph.D Dissertation. University of Ibadan.

. (In Preparation) The Morphopragmatics of Expressive Affixes in Igbo.

Agbo, M. \& C. Yuka. 2011. Transitivity and Double Object Construction in Igbo. Journal of West African Languages 38.2, 33-48.

Cook, T. 2002. Focus in Efik. Journal of African Languages and Linguistics 23.2, 113-152.

Efthymiou, A. 2013. On the Interaction between Semantics and

Phonetic Iconicity in Evaluative Morphology. Skase Journal of

Theoretical Linguistics 10.1, 152-166.

Emenanjo, N. 1978. Elements of Modern Igbo Grammar. Ibadan: 
Oxford University Press.

1985. Auxiliaries in Igbo: A Comparative Study. Bloomington, IN: Indiana Linguistics Club.

. 2005. Igbo Verbs: Transitivity or Complementation. In O.

Ndimele (ed.), Trends in the Study of Languages and Linguistics in Nigeria (A Feschrift for P.A. Nwachukwu) 479-497. Port Harcourt: Grand Orbit Communication \& Emhai Press.

Fortin, A. 2011. The Morphology and Semantics of Expressive Affixes. Ph.D Dissertation. University of Oxford.

di Garbo, F. 2013. Evaluative Morphology and Noun Classification: A Cross-Linguistic Study of Africa. Skase Journal of Theoretical Linguistics 10.1, 114-136.

Hartmann, K. \& M. Zimmermann. 2007. Exhaustivity Marking in Hausa: A Reanalysis of the Particle nee/cee. In E. Aboh et al. (eds.), Focus Strategies in African Languages: The Interaction of Focus and Grammar in Niger-Congo and Afro-Asiatic. Berlin: Walter de Gruyter.

Hyman, L. \& J. Watters. 1984. Auxiliary Focus. Studies in African Linguistics 15.3, 233-273.

Körtvelyessy, L. \& P. Stekauer. 2011. Introduction. Lexis 6, 3. Letsholo, R. 2009. The Forgotten Sructure of Ikalanga Relatives. Studies in African Linguistics 38.2, 131-154.

Mbah, B. et al. 2012. Phonology of Igbo Morpho-Syntactic Clitics. Research on Humanities and Social Sciences 2.6, 176-191.

Nwachukwu, P. 1995. Topic, Focus, and Move Alpha in Igbo. In

N. Emenanjo \& O. Ndimele (eds.), Issues in African Languages and Linguistics: Essays in Honour of Kay Williamson 181-192. Aba: NINLAN Book Series.

Scalise, S. 1984. Generative Morphology. Dordrecht: Foris Publications.

Schachter, P. 1973. Focus and Relativization. Language 49, 19-46. Schwarz, F. 2007. Ex-Situ Focus in Kikuyu. In E. Aboh et al. (eds.), Focus Strategies in African Languages: The Interaction 
78 The Morphosyntactic Coding of Focus Structure in Igbo

of Focus and Grammar in Niger-Congo and Afro-Asiatic 139-159. Berlin: Walter de Gruyter.

Uwalaka, M. 1988. The Igbo Verb: A Semantico-Syntactic Analysis. Wien: AFRO-Publication. . 1997. Igbo Grammar. Ibadan: The Pen Services.

van Valin, R. 2005. Exploring the Syntax-Semantics Interface. Cambridge: Cambridge University Press.

de Vries, M. 2006. The Syntax of Appositive Relativization: On Specifying Coordination, False Free Relatives, and Promotion. Linguistic Inquiry 37.2, 229-270.

Williamson, K. \& R. Blench. 2000. Niger Congo. In B. Heine \& D. Nurse (eds.), African Languages: An Introduction 11-42. Cambridge: Cambridge University Press.

Wolf, E. \& D. Löhr. 2006. Encoding Focus in Kanuri Verbal Morphology: Predication Focus and the 'Kanuri Focus Shift'. ZAS Papers in Linguistics 46, 185-209. 